INDEPENDENT JOURNAL OF MANAGEMENT \& PRODUCTION (IJM\&P)

http://www.ijmp.jor.br

v. 12, n. 4, May-June 2021

ISSN: 2236-269X

DOI: 10.14807/ijmp.v12i4.1380

\title{
THE INFLUENCE OF CORPORATE SOCIAL RESPONSIBILITY ON CORPORATE BRAND EQUITY: A STUDY WITH STRUCTURAL EQUATION MODELING
}

\author{
Paulo Henrique Ceciliano \\ Estácio de Sá University (MADE/UNESA), Brazil \\ E-mail: pauloceciliano1980@gmail.com \\ Paulo Roberto da Costa Vieira \\ Estácio de Sá University (MADE/UNESA), Brazil \\ E-mail: paulo.vieira@estacio.br \\ Antônio Carlos Magalhães da Silva \\ Rio de Janeiro Federal University (COPPE/UFRJ) \\ Estácio de Sá University (MADE/UNESA) \\ Fluminense Federal University (UFF), Brazil \\ E-mail: antonio.msilva@estacio.br \\ Submission: 6/26/2020 \\ Revision: $7 / 30 / 2020$ \\ Accept: 8/15/2020
}

\section{ABSTRACT}

The concept of corporate social responsibility (CSR) plays an important role in corporate marketing and is understood as a strategic variable, because if managed properly, it can increase the corporation's market share. This study investigates the various causal relationships between corporate social responsibility, corporate brand credibility (CBC), corporate reputation (CR) and corporate brand equity (CBE). Data were collected through a survey with a selfadministered structured questionnaire, with five response options scored on a Likert scale. The sample included 310 consumers who expressed their opinions on a large Brazilian oil and gas company. The data were treated through structural equation modeling with partial least squares. The results showed that CSR has direct and indirect effects on CBE. Mixed methods are worthwhile to those who are working on a doctorate research work. Moreover, it will be helpful to develop knowledge through this method that can be beneficial to academia and Practitioners.

Keywords: Corporate Social Responsibility; Corporate Brand Credibility; Corporate Brand Equity; Corporate Reputation; Structural Equation Modeling 
DOI: $10.14807 /$ ijmp.v12i4.1380

\section{INTRODUCTION}

Companies benefit from engagement in CSR activities, since these allow them to construct a positive corporate image and solid reputation over the long run (Bhattacharya \& Sen, 2004; Du et al., 2010; Hur et al., 2014; Melo \& Garrido-Morgado, 2012). CSR activities influence consumers' buying decisions. Several studies have shown that the dimensions social responsibility, philanthropy and ethics can promote beliefs in customers that the company in question is concerned with the well-being of society, resulting in a positive corporate reputation among consumers (Castaldo et al., 2009; Park et al., 2014).

Factors such as satisfaction, loyalty and reputation directly reflect the predisposition of consumers in relation to purchasing the products and/or services offered to them by firms with solid CSR (Bianchi et al., 2019).To the extent that consumers attribute these factors positively to responsible actions, CSR directly affects their purchasing intentions (Ellen et al., 2006). Among companies' intangible assets are credibility and reputation, which are hard to imitate (Rodríguez, 2002). These intangible assets set the company apart and increase the predisposition of consumers to buy its goods and/or services (Aksak et al., 2016; Pirsch et al., 2007).

Companies thus need to invest in CSR programs to enhance the value of their related intangible assets and create positive moral capital, mitigating the potential damages that negative opinions of stakeholders can cause (Godfrey, 2005). When consumers perceive that CSR initiatives are sincere, they tend to trust the company, believing it will continue to honor its promises (Bhattacharya et al., 1998). Corporate brand credibility is based on the perception of trust by consumers in the company, and this construct, along with corporate reputation, has an impact on the brand equity (Hur et al., 2014). This study examines the causal relationship between CSR and corporate brand equity, including credibility and reputation as mediating latent variables.

\section{LITERATURE REVIEW}

This section briefly discusses the literature on the main constructs of the hypothetical model to be tested, to establish a firm foundation for the model's hypotheses.

\subsection{Corporate social responsibility}

CSR voluntarily integrates social and environmental questions in the commercial activities of companies and their relationships with stakeholders, according to which they are willing to sacrifice profits in favor of social interests. Firms should consider environmental, 
DOI: $10.14807 /$ ijmp.v12i4.1380

social and economic responsibility in their decisions, going beyond simple philanthropy (Witkowska, 2016). Bowen (1953, p. 6) was the first observer to formulate the concept of CSR, according to whom businesses have "the obligation to pursue policies, decisions, or lines of action desirable to achieve the objectives and values of our society."

Carroll (1979) proposed a widely accepted concept, considering four spheres of CSR: economic, legal, ethical and discretionary. Discretionary responsibility refers to the voluntary initiatives of a firm related to solutions of social problems. CSR is generally considered to denote actions that go beyond what the law requires, such as voluntary granting of fringe benefits to employees. In its broadest sense, CSR represents a concern for the needs and objectives of society beyond merely economic considerations (Eells \& Walton, 1974; Sims, 2003).

There are two basic views of CSR, classified as ethical and instrumental (Pedersen \& Neergaard, 2009). The ethical view advocates that companies should adopt socially responsible actions, even if this might mean unproductive expenditures in the short run. On the other hand, the instrumental view considers the existence of a positive correlation between socially responsible behavior and financial performance.

Nowadays, the idea of sustainable development is closely associated with CSR activities, according to which the overarching objective of all economic agents should be to meet the needs of the current generation without compromising the development of future generations (Bianchi et al., 2019; Bouglet et al., 2012). In particular, CSR initiatives can be associated with sustainable development based on the triple bottom line (TBL) idea of Elkington (1998). The essence of the TBL concept is three pillars widely addressed by CSR social, environmental and economic - considered as essential constituents of the business dealings of companies (Nadanyiova \& Gajanova, 2020).

Therefore, the focus on economic results has been expanded to include improvement of the main business processes of firms, defined as those whose objective is to minimize the negative consequences of business activities on development of the economic climate. These processes include formulation of corporate codes of ethics, provision of transparent information, rejection of corruption, protection of intellectual property, supply of high-quality products and services, innovation and sustainability of products, and good relations with customers and investors (Pavlík et al., 2010).

Corporate social responsibility can improve the relationship between a firm and its stakeholders. Thus, besides offering new investment opportunities, CSR also improves the financial performance in terms of costs and revenues (Barnett, 2007; Lai et al., 2010). Socially 
DOI: $10.14807 /$ ijmp.v12i4.1380

responsible companies stand from their competitors because their positive attitudes are reflected in the buying intentions of consumers (Pivato et al.,2008).

\subsection{Corporate credibility}

The concept of corporate credibility refers to the perceptions of consumers and other stakeholders regarding the actions and intentions of the company (Goldsmith et al., 2000). Corporate credibility is associated with the trust that the firm will meet its promises (Herbig \& Milewicz, 1995). In the long run, credibility forges a solid reputation, which is fundamental for the success of the brand and marketing strategy.

Corporate credibility directly increases the value of brands (brand equity). On the other hand, lack of credibility leads consumers to doubt the validity or sincerity of promises made, negatively influencing the likelihood they will buy a firm's products or services (Aaker \& Joachimsthaler, 2000). Therefore, the main challenge faced by companies in disclosing their CSR strategy is to assure credibility in relation to the information disclosed in their reports (Gray, 2000; Martínez-Ferrero et al., 2015; Odriozola \& Baraibar-Diez, 2017). A positive corporate reputation promotes positive attitudes of consumers toward the firm, strengthening their buying intentions (Lafferty \& Goldsmith, 1999).

Credible brands indicate the positioning of a product, influencing consumers to perceive less risk, thus reducing their need to gather information before making their purchasing decisions (Srinivasan \& Ratchford, 1991). Credible CSR initiatives reduce information asymmetry and the need for monitoring, which are particularly important in the case of large and complex organizations. This reduction of information asymmetry enhances positive attitudes toward the company, thus increasing is brand equity and attracting more investments (Zajac \& Westphal, 1994).

\subsection{Corporate reputation}

Intangible resources, such as corporate reputation, culture and capability, contribute to improve the financial performance, especially to the extent they are scarce and cannot be imitated or substituted. In the vision of the resource based theory, these assets generate sustainable competitive advantages to companies that can adeptly control and manage them (Branco \& Rodrigues, 2006).

A firm's reputation has been widely recognized as one of the basic pillars of success (Key, 1995). A positive reputation is considered one of the most valuable intangible assets a firm can possess (Vidaver-Cohen, 2007). But reputation is highly subjective, because it rests 
DOI: $10.14807 /$ ijmp.v12i4.1380

on a perception, which is the result of the aggregate visions about it, based on the experiences of stakeholders in its respect (Cornelissen, 2011; Fombrun et al.,2000; Roberts, 2009).

Academics and business professionals agree that a positive reputation reduces the uncertainty of stakeholders about the future organizational performance, improves the competitive advantage, increases public trust and maximizes the ability to charge premium prices for goods and/or services (Vidaver-Cohen, 2007). Therefore, consumers rely in corporate reputation to evaluate a product or service (Schnietz \& Epstein, 2005). When a company enjoys a favorable reputation, customers become more loyal and less concerned about price; job candidates are more desirous of being hired; investors are more willing to provide capital; and local communities tend to be more laudatory (Fombrun, 1996; Lange et al., 2010; Turban \& Greening, 1997).

\subsection{Corporate brand equity}

Corporate brand equity positively influences a sustainable competitive advantage, the success of marketing actions, and the price of the firm's shares (Ambler, 1997; Bharadwaj et al., 1993; Lane \& Jacobson, 1995). The approaches used to measure brand equity are generally financial or customer-related. The financial measures are represented by movements in the stock price (Myers, 2003). The customer-related measures can be classified in two groups: i) those related to perceptions (e.g., brand recognition, perceived association with quality); and ii) those associated with behavior (e.g., brand loyalty and buying behavior) (Hsu, 2012).

\section{HYPOTHESES DEVELOPMENT}

Bhattacharya and Sen (2003) studied the behavior of consumers and found they are not only concerned with their experience with a product or service, but also with the effects on other stakeholders from the community. Therefore, stakeholders exhibit stronger identification with firms that implement strong CSR initiatives than with those that do not. In this sense, a firm's CSR initiatives can cause a favorable impression on consumers who are sensitive to social questions (Pivato et al., 2008).

Considering that corporate brand credibility is a two-dimensional construct, composed of trust and expertise, is it possible to infer that CSR activities influence the convictions of consumers that the firm makes products with higher quality by signaling greater management competence (Mcwilliams \& Siegel, 2001; Newell \& Goldsmith, 2001). Based on these arguments, it is possible to formulate the following hypothesis: 
DOI: $10.14807 /$ ijmp.v12i4.1380

\section{- H1 - Corporate social responsibility directly impacts corporate credibility.}

A company will not only benefit from involvement in CSR initiatives, these will benefit society as a whole. It is crucial for firms to recognize that CSR activities influence the construction of their reputation (Hasan \& Yun, 2017). In the case of long-range competitive advantages, reputation is the indicator that measures the accrued prestige, allowing companies to build a loyal customer base while at the same time reducing the risks related to stakeholders (Siano et al., 2010).

Companies justify CSR initiatives because they enhance their corporate image and establish the foundations for a solid long-term reputation (Jones, 2005; Porter \& Kramer, 2006). The maintenance of a solid corporate reputation can be equated with making a lucrative strategic investment (Fombrun, 2005; Mcwilliams et al., 2006). Consumers’ perceptions about the CSR activities are positively related with the firm's reputation (Hsu, 2012; Lai et al., 2010). The aspects described above lead to the following hypothesis:

- H2 - Corporate social responsibility directly impacts corporate reputation.

Lai et al. (2010) suggested that the favorable perception of consumers about CSR activities is positively related to their vision of the brand. Other researchers have reported that CSR has a positive effect on the recognition and valuation a firm's brand, which improves the company's position in the market (Holt et al., 2004). In this respect, we propose the following hypothesis:

- H3 - Corporate social responsibility directly impacts corporate brand equity.

Consumers look favorably on organizations that adopt CSR practices when they believe these activities are the result of sincere intentions (Vlachos et al., 2009). To the extent that consumers concur with these practices, since they reflect their basic beliefs, the engagement in CSR encourages consumers to view an ethical stance in those actions. This perception of ethics leads to recognition of trustworthy behavior, increasing the corporation's credibility and strengthening its reputation (Fombrun \& Shanley, 1990; Hosmer, 1995; Smaiziene \& Jucevicius, 2009).

Consumers assume that a trustworthy company will be less likely to fail to meet its promises, thus strengthening its reputation (Pivato et al., 2008). This leads to the following hypothesis:

- H4 - Corporate credibility directly impacts corporate reputation. 
DOI: $10.14807 /$ ijmp.v12i4.1380

The way that consumers perceive CSR actions can affect the corporate reputation and their buying intentions. Several studies have suggested that a positive correlation exists between corporate reputation and brand equity. For example, Mohr, Webb and Harris (2001) showed that the evaluation of firms, their products and consumers' buying intentions depends on the quantity and nature of CSR information that is shared. Chaudhuri (2002) suggested that corporate reputation is in a higher position than brand equity, by supplying exclusive value to a firm's customers, thus generating higher brand value than that of competitors.

Corporate reputation is an intangible resource that can lead to a positive attitude of consumers in relation to the brand of the product or service offered by the firm, enhancing the brand equity (Galbreath,2005). Based on these observations, we formulated the following hypothesis:

\section{- H5 - Corporate reputation directly impacts corporate brand equity.}

The relationship between corporate credibility and brand equity can be explained by the brand signaling theory. According to this theory, brands serve as signals to convey information to target consumers, who are inserted in a market filled with imperfect and asymmetrical information (Erdem \& Swait, 2001; Erdem et al., 2006).

Credible brands enjoy lower information processing costs and are associated with lower risk perception. The credibility of a brand is the central pillar around which a company can build and manage its brand equity (Jahanzeb et al., 2013; Spry et al., 2011). Based on these arguments, we formulated the following hypothesis:

\section{- H6 - Corporate credibility directly impacts brand equity.}

The path diagram in Figure 1 illustrates the causal relations between the constructs and hypotheses discussed above.

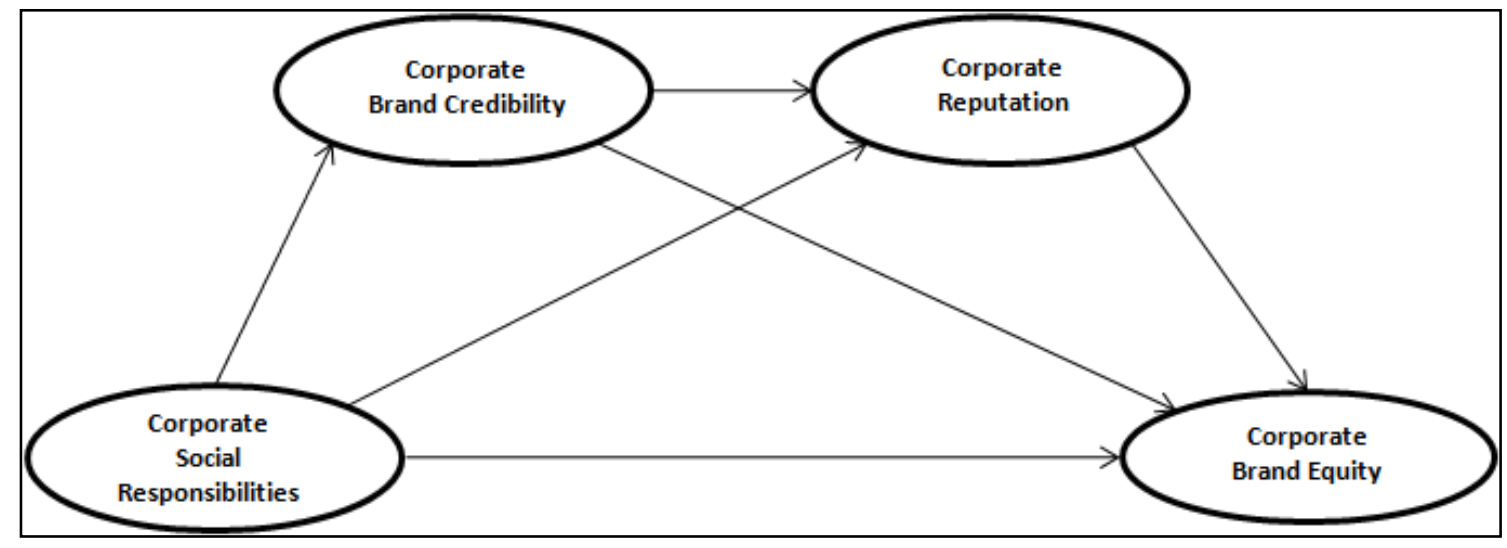

Figure 1: Path diagram of the hypothetical model

Source: Proposal conceptual model, adapted from Hur et al. (2014) 
INDEPENDENT JOURNAL OF MANAGEMENT \& PRODUCTION (IJM\&P)

http://www.ijmp.jor.br

v. 12, n. 4, May-June 2021

ISSN: 2236-269X

DOI: 10.14807/ijmp.v12i4.1380

\section{METHODOLOGY}

The data for this study were obtained through a survey using a structured questionnaire, and were treated with structural equation modeling with the support of the partial least squares method to evaluate the causal connections between the constructs.

\subsection{Data collection}

We collected the opinions of consumers regarding an important Brazilian company in the oil and gas sector. It is a listed corporation and is active in the exploration, production, refining, transport and sale of oil and natural gas, as well as the manufacture of petrochemicals and biofuels and generation of electricity. The consumers were approached at service stations, repair shops and specialized automotive stores. The company studied has received several international awards and certifications in the petroleum sector, and has a policy of rendering transparent information to its stakeholders through sustainability reports regularly disclosed to the public at large.

The survey was conducted by means of a self-administered questionnaire, with items scored on a Likert scale with five response options. Each respondent participated voluntarily in the survey. Any doubts were clarified by the researcher while applying the questionnaire. All told, 310 valid questionnaires were obtained, of which 16 were dropped for containing outliers. The descriptive analysis revealed that $77.7 \%$ of the respondents were men, with average age of 39.07 years $(S D=8.60)$ and age range from 20 to 65 years. With respect to schooling level, $31.7 \%$ of the respondents only had high school diplomas, while $35.4 \%$ had college degrees, 31.5\% had MBA or MSc degrees, and only 1.4\% had doctorates (PhDs). With respect to occupation, 9.4\% were students or unemployed workers, $56.2 \%$ were employees of a company, institution or other organization, $28.1 \%$ were freelance service providers or merchants, and $6.3 \%$ were retirees.

The questions covered the CSR practices of the target company. The constructs and respective observed and latent variables of the hypothetical model are reported in Chart 1.

Chart 1: Latent variables, observed variables and respective references

\begin{tabular}{|c|c|c|}
\hline Latent variable & Observed variable & References \\
\hline \multirow{4}{*}{$\begin{array}{c}\text { Corporate Social } \\
\text { Responsibility (CSR) }\end{array}$} & $\begin{array}{c}\text { CSR_1 - adherence to } \\
\text { responsible corporate behavior }\end{array}$ & $\begin{array}{c}\text { Barnett (2007); Carroll (1979); Lai et } \\
\text { al.(2010); Pivato et al.(2008); }\end{array}$ \\
\cline { 2 - 3 } & $\begin{array}{c}\text { CSR_2 - policies to improve } \\
\text { social well-being }\end{array}$ & $\begin{array}{c}\text { Bowen (1953); Eells \& Walton (1974); Sims } \\
\text { (2003) }\end{array}$ \\
\cline { 2 - 3 } & $\begin{array}{c}\text { CSR_3 - environmental } \\
\text { responsibility }\end{array}$ & $\begin{array}{c}\text { Bianchi et al. (2019); Bouglet et al.(2012); } \\
\text { Elkington (1998) }\end{array}$ \\
\hline Corporate Brand & $\begin{array}{c}\text { CBC_1 - reliability of } \\
\text { information and corporate } \\
\text { attitudes }\end{array}$ & $\begin{array}{c}\text { Goldsmith et al.(2000); Herbig \& Milewicz } \\
\text { (1995) }\end{array}$ \\
\hline
\end{tabular}


INDEPENDENT JOURNAL OF MANAGEMENT \& PRODUCTION (IJM\&P)

http://www.ijmp.jor.br

v. 12, n. 4, May-June 2021

ISSN: 2236-269X

DOI: 10.14807/ijmp.v12i4.1380

\begin{tabular}{|c|c|c|}
\hline Latent variable & Observed variable & References \\
\hline & $\begin{array}{l}\text { CBC_2 - reliability of products } \\
\text { and services }\end{array}$ & Aaker \& Joachimsthaler (2000) \\
\hline & $\begin{array}{l}\text { CBC_3 - reliability of corporate } \\
\text { brand }\end{array}$ & $\begin{array}{c}\text { Srinivasan \& Ratchford (1991); Zajac \& } \\
\text { Westphal (1994) }\end{array}$ \\
\hline \multirow{4}{*}{$\begin{array}{l}\text { Corporate Brand Equity } \\
\text { (CBE) }\end{array}$} & $\begin{array}{c}\text { CBE_1 - recognition among } \\
\text { competitors }\end{array}$ & $\begin{array}{c}\text { Branco \& Rodrigues (2006); Chaudhuri } \\
(2002)\end{array}$ \\
\hline & $\begin{array}{l}\text { CBE_2 - ethics and values in } \\
\text { symmetry with customers }\end{array}$ & Hur et al.(2014); Myers (2003) \\
\hline & $\begin{array}{l}\text { CBE_3 - associations of the } \\
\text { corporate brand }\end{array}$ & Erdem \& Swait (2001); Erdem et al. (2006) \\
\hline & $\begin{array}{l}\text { CBE_ } 4-\text { recognition of the } \\
\text { corporate brand }\end{array}$ & Hsu (2012) \\
\hline \multirow{3}{*}{$\begin{array}{l}\text { Corporate Reputation } \\
\text { (CR) }\end{array}$} & CR_1 - perception of reliability & $\begin{array}{l}\text { Cornelissen (2011); Fombrun et al.(2000); } \\
\text { Roberts (2009); Vidaver-Cohen (2007) }\end{array}$ \\
\hline & $\begin{array}{l}\text { CR_2 - perception of admiration } \\
\text { and respect }\end{array}$ & $\begin{array}{c}\text { Fombrun (1996); Lange et al.(2010); Turban } \\
\text { \& Greening (1997) }\end{array}$ \\
\hline & $\begin{array}{l}\text { CR_3 - perception of good } \\
\text { general reputation }\end{array}$ & Hasan \& Yun (2017); Siano et al.(2010) \\
\hline
\end{tabular}

\subsection{Treatment of the data}

The data were treated with structural equation modeling (SEM) by applying partial least squares (PLS). The latter technique is effective to analyze endogenous variables in statistical models whose structure is designed to elicit causal relationships. It is particularly suitable when the sample is relatively small, there is no knowledge of the normality of the data, and the model is complex, containing many latent variables (Hair \& Sarstedt, 2019). The data were treated with the WarpPLS software, version 7.0.

The results were analyzed in two steps. The first step involved evaluation of the measurement model, while the second entailed assessment of the structural model (Henseler et al., 2009; Hair, et al., 2014).

\section{RESULTS}

The measurement model, also called the external model, exhibits the relationships between the latent variables and the respective observed variables, while the structural model indicates the pairwise causal connections between the constructs.

\subsection{Measurement model}

The main indices of the measurement model are Cronbach's alpha, composite reliability and the average variance extracted (AVE). The first two measure the model's internal consistency and the last the convergent validity.

Table 1: Index of reliability and convergent validity

\begin{tabular}{cccc}
\hline Latent variable & Composite reability & Cronbach's alpha & AVE \\
\hline CSR & 0.850 & 0.735 & 0.655 \\
CBC & 0.885 & 0.804 & 0.719 \\
\hline
\end{tabular}


INDEPENDENT JOURNAL OF MANAGEMENT \& PRODUCTION (IJM\&P)

http://www.ijmp.jor.br

v. 12, n. 4, May-June 2021

ISSN: 2236-269X

DOI: $10.14807 /$ ijmp.v12i4.1380

\begin{tabular}{cccc}
\hline $\mathbf{C R}$ & 0.914 & 0.858 & 0.779 \\
$\mathbf{C B E}$ & 0.881 & 0.820 & 0.650 \\
\hline
\end{tabular}

Cronbach's alpha measures the internal consistency of the observed variables, and should be above 0.70 for each construct of the model. The results were favorable for all the constructs. The composite reability also measures the internal consistency of the indicators. This consistency is necessary for the model's validity. Values between 0.70 and 0.90 , or in the neighborhood of that interval, are considered satisfactory. In this study, the composite reability results were adequate (Hair et al., 2014; Hair et al., 2016; Ringle et al., 2014).

The AVE can be considered a measure of the variance shared by the observed variables of a determined construct, and should be greater than 0.50. It is applied to measure the convergent validity of the model. In this study, the AVE was greater than 0.50 for all the constructs (Hair et al., 2014; Hair et al., 2016; Henseler et al., 2016).

To assess the discriminant validity, we considered the cross-loading criterion, because it enables verifying the magnitude of the loadings as well as the signs and significance of the observed variables of each construct.

Table 2: Cross loadings and statistical significance

\begin{tabular}{|c|c|c|c|c|c|c|c|}
\hline & CSR & CBC & CR & CBE & Type & SE & P-value \\
\hline CSR_1 & $\mathbf{0 . 8 4 4}$ & -0.000 & -0.130 & 0.038 & Reflective & 0.050 & $<0.001$ \\
\hline CSR_2 & $\mathbf{0 . 7 4 8}$ & -0.217 & 0.204 & 0.007 & Reflective & 0.051 & $<0.001$ \\
\hline CSR_3 & $\mathbf{0 . 8 3 3}$ & 0.195 & -0.052 & -0.045 & Reflective & 0.050 & $<0.001$ \\
\hline CBC_1 & -0.049 & $\mathbf{0 . 8 0 6}$ & 0.101 & -0.297 & Reflective & 0.050 & $<0.001$ \\
\hline CBC_2 & -0.006 & $\mathbf{0 . 8 6 7}$ & -0.232 & 0.204 & Reflective & 0.050 & $<0.001$ \\
\hline CBC_3 & 0.051 & $\mathbf{0 . 8 7 0}$ & 0.138 & 0.072 & Reflective & 0.050 & $<0.001$ \\
\hline CR_1 & -0.044 & -0.017 & $\mathbf{0 . 8 9 2}$ & 0.062 & Reflective & 0.049 & $<0.001$ \\
\hline CR_2 & 0.023 & 0.086 & $\mathbf{0 . 9 0 0}$ & 0.060 & Reflective & 0.049 & $<0.001$ \\
\hline CR_3 & 0.022 & -0.073 & $\mathbf{0 . 8 5 5}$ & -0.129 & Reflective & 0.050 & $<0.001$ \\
\hline CBE_1 & 0.148 & 0.022 & -0.254 & $\mathbf{0 . 7 8 3}$ & Reflective & 0.050 & $<0.001$ \\
\hline CBE_2 & 0.003 & 0.053 & 0.054 & $\mathbf{0 . 8 2 5}$ & Reflective & 0.050 & $<0.001$ \\
\hline CBE_3 & -0.065 & -0.207 & 0.144 & $\mathbf{0 . 7 9 4}$ & Reflective & 0.050 & $<0.001$ \\
\hline CBE_4 & -0.081 & 0.126 & 0.049 & $\mathbf{0 . 8 2 2}$ & Reflective & 0.050 & $<0.001$ \\
\hline
\end{tabular}

The objective of examining the cross loadings is to determine whether the loadings of the observed variables related to the respective construct are greater than it or to adjacent constructs. In this study, the loadings of the observed variables in each construct were greater than it, with magnitudes larger than 0.708 , and presented statistical significance, as predicted by the theory (Hair et al., 2016; Henseler et al., 2016).

\subsection{Structural model}

The path coefficients of the structural model should be statistically significant, as well as having the signs predicted by the theory (Hair et al., 2014). 
DOI: 10.14807/ijmp.v12i4.1380

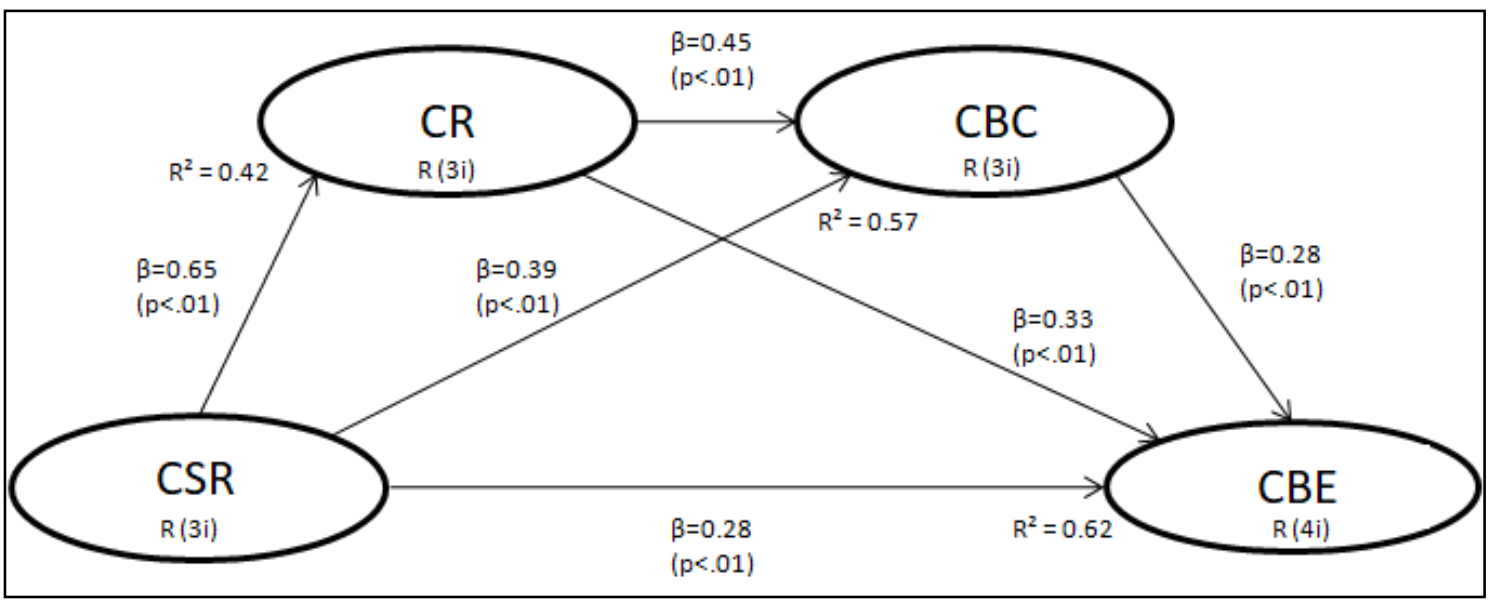

Figure 2: Path diagram and results of the hypothetical model

Figure 2 and Table 3 show that the path coefficients had the signs predicted by the theory, with statistical significance.

Table 3: Path coefficients and statistical significance

\begin{tabular}{|c|c|c|c|}
\hline \multicolumn{4}{|c|}{ Path Coefficients } \\
\hline & CSR & CBC & CR \\
\hline CBC & 0.651 & & \\
\hline CR & 0.389 & 0.447 & \\
\hline CBE & 0.282 & 0.328 & 0.282 \\
\hline \multicolumn{4}{|c|}{ Statistical Significance } \\
\hline & CSR & CBC & CR \\
\hline CBC & $<0.001$ & & \\
\hline CR & $<0.001$ & $<0.001$ & \\
\hline CBE & $<0.001$ & $<0.001$ & $<0.001$ \\
\hline
\end{tabular}

Pearson's coefficient of determination $\left(\mathrm{R}^{2}\right)$ is a predictive indicator of the model that allows analyzing the influence of exogenous latent variables on the endogenous latent variables. The $\mathrm{R}^{2}$ value varies from 0 to 1 , where by the nearer it is to 1 , the more precise the prediction will be (Hair et al., 2014). Here, these coefficients exhibited consistent results, as shown in Table 4.

Table 4: Coefficients of determination $\left(\mathrm{R}^{2}\right)$

\begin{tabular}{|c|c|c|}
\hline CBC & CR & CBE \\
\hline 0.424 & 0.575 & 0.620 \\
\hline
\end{tabular}

\section{CONCLUSION AND DIRECTIONS FOR FUTURE RESEARCH}

The acceptance of all the proposed hypotheses attests to the essential nature of corporate social responsibility, by exerting direct and indirect impacts on corporate brand equity. In this study, besides the direct impact on brand equity, CSR had an indirect impact by means of corporate credibility and reputation. 
DOI: 10.14807/ijmp.v12i4.1380

CSR should not be viewed as an unrecoverable expenditure, since it has a strong positive impact on credibility and reputation, thus representing an investment whose fruits will be harvested in the future. CSR affects firms' credibility, but also exerts a strong influence on reputation, as proposed by the theory. As mentioned earlier, corporate reputation is a rare and valuable asset that is hard to imitate, thus making an inestimable contribution to the formulation of business strategy.

In the case of the corporation studied here, CSR and credibility together explained 57\% of the variance of its reputation. This result shows that the company's social responsibility practices, which are not limited to care for the environment according to its published reports (also including relations with employees), have been successful, with broad national recognition.

The impacts caused by CSR will be translated into gains of the company, more specifically by increasing sales revenue and decreasing costs. The stronger a firm's reputation is, the more motivated its employees will be, meaning higher productivity. Furthermore, by creating psychological income, a good reputation attracts more talented job applicants, since employees take pride in working for a company with a good reputation.

In the case here, the strengthening of the corporate brand equity will also facilitate penetration in the international downstream market, which is composed of customers who are increasingly exigent regarding the environmental footprint of their suppliers. The results of this study demonstrate that companies should not ignore social responsibility practices, because they positively affect rare and unique assets, such as credibility and reputation.

The study has some limitations. Chief among them is the use of a convenience sample, which prevents generalization of the results. Therefore, we recommend using random samples in future studies. The sample was also limited to consumers in the Brazilian market, leaving room for future studies including consumers from other countries.

The hypothetical model was applied to a single company. Future studies could include other firms in the oil and gas sector, or companies in other sectors. Finally, the study did not consider all the dimensions of corporate social responsibility, so future works can analyze whether the economic, legal, ethical and philanthropic dimensions have similar or different effects on corporate brand equity.

\section{REFERENCES}

Aaker, D. A., \& Joachimsthaler, E. (2000). Brand Leadership. New York: The Free Press. 
Ambler, T. (1997). How much of brand equity is explained by trust? Management Decision, 35(4), 283-292.

Aksak, E. O., Ferguson, M. A., \& Duman, S. A. (2016). Corporate social responsibility and CSR fit as predictors of corporate reputation: A global perspective. Public Relations Review, 42(1), 79-81.

Barnett, M. L. (2007). Stakeholder influence capacity and the variability of financial returns to corporate social responsibility. Academy of Management Review, 32(3), 794-816.

Bharadwaj, S. G., Varadarajan, P. R., \& Fahy, J. (1993). Sustainable competitive advantage in service industries: A conceptual model and research propositions. Journal of Marketing, 57(4), 83-99.

Bhattacharya, R., Devinney, T. M., \& Pillutla, M. M. (1998). A formal model of trust based on outcomes. Academy of management review, 23(3), 459-472.

Bhattacharya, C. B., \& Sen, S. (2003). Consumer-Company Identification: A Framework for Understanding Consumers' Relationships with Companies. Journal of Marketing, 67(2), 76-88.

Bhattacharya, C. B., \& Sen, S. (2004). Doing better at doing good: When, why, and how consumers respond to corporate social initiatives. California management review, 47(1), 924.

Bianchi, E., Bruno, J. M., \& Sarabia-Sanchez, F. J. (2019). The impact of perceived CSR on corporate reputation and purchase intention. European Journal of Management and Business Economics, 28(3), 206-221.

Bouglet, J., Joffre, O., \& Simon, E. (2012). How to reconcile business with sustainable development: an innovation approach. Society and Business Review, 7(3), 212-222.

Bowen, H. R. (1953). Social Responsibilities of the Businessman. Harper \& Row. New York.

Branco, M. C., \& Rodrigues, L. L. (2006). Corporate Social Responsibility and ResourceBased Perspectives. Journal of Business Ethics, 69(2), 111-132.

Carroll, A. B. (1979). A three-dimensional conceptual model of corporate performance. Academy of management review, 4(4), 497-505.

Castaldo, S., Perrini, F., Misani, N., \& Tencati, A. (2009). The missing link between corporate social responsibility and consumer trust: The case of fair trade products. Journal of business ethics, 84(1), 1-15.

Chaudhuri, A. (2002). How brand reputation affects the advertising-brand equity link. Journal of Advertising Research, 42(3), 33-43.

Cornelissen, J. P. (2011). Corporate Communication: A guide to theory and practice (3rd ed.).. London: Sage.

Du, S; Bhattacharya, C. B., \& Sen, S. (2010). Maximizing business returns to corporate social responsibility (CSR).: The role of CSR communication. International journal of management reviews, 12(1), 8-19.

Eells, R., \& Walton, C. (1974). Conceptual Foundations of Business. (3rd ed.).. Illinois: Irwin. 
Ellen, P. S., Webb, D. J., \& Mohr, L. A. (2006). Building corporate associations: Consumer attributions for corporate socially responsible programs. Journal of the academy of Marketing Science, 34(2), 147-157.

Elkington, J. (1998). Partnerships from cannibals with forks: The triple bottom line of 21 stcentury business. Environmental Quality Management, 8(1), 37-51.

Erdem, T., \& Swait, J. (2001). Brand equity as a signaling. Journal of Consumer Psychology, 7(2), 131-157.

Erdem, T., Swait, J., \& Valenzuela, A. (2006). Brands as signals: A cross-country validation study. Journal of Marketing, 70(1), 34-49.

Fombrun C., \& Shanley, M. (1990). What's in a name? Reputation building and corporate strategy. Academy of Management Journal, 33(2), 233-258.

Fombrun, C. J. (1996). Reputation. Boston: Harvard Business School Press.

Fombrun, C. J., Gardberg, N. A., \& Sever, J. I. (2000). The reputation quotient: a multistakeholder measure of corporate reputation. The Journal of Brand Management, 7(4), 241255.

Fombrun, C. J. (2005). The leadership challenge: Building resilient corporate reputations. Handbook on responsible leadership and governance in global business, 54), 68.

Galbreath, J. (2005). Which resources matter the most to firm success? An exploratory study of resource-based theory. Technovation, 25(9), 979-987.

Godfrey, P. C. (2005). The relationship between corporate philanthropy and shareholder wealth: A risk management perspective. Academy of management review, 30(4), 777-798.

Goldsmith, R. E., Lafferty, B. A., \& Newell, S. J. (2000). The influence of corporate credibility on consumer attitudes and purchase intent. Corporate Reputation Review, 3(4), 304-318.

Gray, R. (2000). Current developments and trends in social and environmental auditing, reporting and attestation: a review and comment. International Journal of Auditing, 4(3), 247-268.

Hair Jr, J. F., Sarstedt, M., Hopkins, L., \& Kuppelwieser, V. G. (2014). Partial least squares structural equation modeling (PLS-SEM).: An emerging tool in business research.European Business Review, 26(2), 106-121

Hair Jr, J. F., Hult, G. T. M., Ringle, C., \& Sarstedt, M. (2016). A primer on partial least squares structural equation modeling (PLS-SEM).. Sage Publications.

Hair Jr, J. F., \& Sarstedt, M. (2019). Factors versus composites: Guidelines for choosing the right structural equation modeling method. Project Management Journal, 50(6), 619-624.

Hasan, R., \& Yun, T. M. (2017). Theoretical link age between corporate social responsibility and corporate reputation. Indonesian Journal of Sustainability Accounting and Management, 1(2), 80-89.

Henseler, J., Ringle, C. M; \& Sinkovics, R. R. (2009). The use of partial least squares path modeling in international marketing. New Challenges to International Marketing (Advances in International Marketing, Emerald Group Publishing Limited, Bingley, 20, 277319.

Henseler, J., Hubona, G., \& Ray, P. A. (2016). Using PLS path modeling in new technology research: Updated guidelines. Industrial Management \& Data Systems, 116(1), 2-20. 
Herbig, P., \& Milewicz, J. (1995). The relationship of reputation and credibility to brand success. Journal of Consumer Marketing, 12(4), 5-11.

Holt, D. B., Quelch, J. A., \& Taylor, E. L. (2004). How global brands compete. Harvard Business Review, 82(9), 68-75.

Hosmer, L. T. (1995). Trust: The connecting link between organizational theory and philosophical ethics. Academy of Management Review, 20(2), 379-403.

Hur, Wm., Kim, H., \& Woo, J. (2014). How CSR leads to corporate brand equity: Mediating mechanisms of corporate brand credibility and reputation. Journal of Business Ethics, 125(1), 75-86.

Hsu, K. T. (2012). The advertising effects of corporate social responsibility on corporate reputation and brand equity: Evidence from the life insurance industry in Taiwan. Journal of Business Ethics, 109(2), 189-201.

Jahanzeb, S., Fatima, T., \& Butt, M. M. (2013). How service quality influences brand equity. International Journal of Bank Marketing, 31(2), 126-141.

Jones, R. (2005). Finding sources of brand value: Developing a stakeholder model of brand equity. Journal of Brand Management, 13(1), 10-32.

Key, J. (1995). Foundations of Corporate Success: How business strategies add value. Oxford: Oxford University Press.

Lafferty, B. A., \& Goldsmith, R. E. (1999). Corporate credibility's role in consumers’ attitudes and purchase intentions when a high versus a low credibility endorser is used in the ad. Journal of Business Research, 44(2), 109-116.

Lai, C. S., Chiu, C. J., Yang, C. F., \& Pai, D. C. (2010). The effects of corporate social responsibility on brand performance: the mediating effect of industrial brand equity and corporate reputation. Journal of Business Ethics, 95(3), 457-469.

Lane, V., \& Jacobson, R. (1995). Stock market reactions to brand extension announcements: The effects of brand attitude and familiarity. Journal of Marketing, 59(1), 63-77.

Lange, D., Lee, P. M., \& Dai, Y. (2011). Organizational reputation: A review. Journal of Management, 37(1), 153-184.

Martínez-Ferrero, J., Garcia-Sanchez, I. M., \& Cuadrado-Ballesteros, B. (2015). Effect of financial reporting quality on sustainability information disclosure. Corporate Social

Responsibility and Environmental Management, 22(1), 45-64.

Mcwilliams, A., \& Siegel, D. (2001). Corporate social responsibility: A theory of the firm perspective. Academy of Management Review, 26(1), 117-127.

Mcwilliams, A., Siegel, D. S., \& Wright, P. M. (2006). Corporate Social Responsibility: Strategic Implications. Journal of Management Studies, 43(1), 1-18.

Melo, T., \& Garrido-Morgado, A. (2012). Corporate reputation: A combination of social responsibility and industry. Corporate social responsibility and environmental management, 19(1), 11-31.

Mohr, L. A., Webb, D. J., \& Harris, K. E. (2001). Do consumers expect companies to be socially responsible? The impact of corporate social responsibility on buying behavior.

Journal of Consumer Affairs, 35(1), 45-72.

Myers, C. A. (2003). Managing brand equity: a look at the impact of attributes. Journal of Product and Brand Management, 12(1), 39-51. 
Nadanyiova, M., \& Gajanova, L. (2020). The impact of Corporate Social Responsibility on brand loyalty in the process of globalization. In: SHS Web of Conferences. EDP Sciences. p. 04017.

Newell, S. J., \& Goldsmith, R. E. (2001). The development of a scale to measure perceived corporate credibility. Journal of Business Research, 52(3), 235-247.

Odriozola, M. D., \& Baraibar-Diez, E. (2017). Is corporate reputation associated with quality of CSR reporting? Evidence from Spain. Corporate Social Responsibility and

Environmental Management, 24(2), 121-132.

Park, J., Lee, H., \& Kim, C. (2014). Corporate social responsibilities, consumer trust and corporate reputation: South Korean consumers' perspectives. Journal of Business Research, 67(3), 295-302.

Pavlík, M., Bělčík, M., Srpová, J., Kunz, V., \& Kužel, S. (2010). Společenská odpovědnost organizace, Grada Publishing.

Pirsch, J., Gupta, S., \& Grau, S. L. (2007). A framework for understanding corporate social responsibility programs as a continuum: An exploratory study. Journal of business ethics, 70(2), 125-140.

Pivato, S., Misani, N., \& Tencati, A. (2008). The impact of corporate social responsibility on consumer trust: the case of organic food. Business Ethics: A European Review, 17(1), 312.

Porter, M. E., \& Kramer, M. R. (2006). The link between competitive advantage and corporate social responsibility. Harvard Business Review, 84(12), 78-92.

Pedersen, R. E., \& Neergaard, P. (2009). What matters to managers? The whats, whys, and hows of corporate social responsibility in a multinational corporation. Management Decision, 47(8), 1261-1280.

Ringle, C. M., Da Silva, D., \& Bido, D. D. S. (2014). Modelagem de equações estruturais com utilização do SmartPLS. Revista Brasileira de Marketing, 13(2), 56-73.

Roberts, D. (2009). Reputation management for education: A review of the academic and professional literature. London: The Knowledge Partnerships.

Rodríguez, F. J. G. (2002). La reputación como recurso estratégico: un enfoque de recursos y capacidades. Doctoral dissertation, Universidad de La Laguna, San Cristóbal de La Laguna, Santa Cruz de Tenerife - Spain, La Laguna.

Siano, A., Kitchen, P. J., \& Confetto, M. G. (2010). Financial resources and corporate reputation: Toward common management principles for managing corporate reputation. Corporate Communications: An International Journal, 15(1), 68-82.

Schnietz, K. E., \& Epstein, M. J. (2005). Exploring the financial value of a reputation for corporate social responsibility during a crisis. Corporate Reputation Review, 7(4), 327-345.

Sims, R. R. (2003). Ethics and corporate social responsibility: Why giants fall. Greenwood Publishing Group.

Smaiziene, I., \&Jucevicius, R. (2009). Corporate reputation: Multidisciplinary richness and search for a relevant definition. Engineering Economics, 62(2), 91-101.

Spry, A., Pappu, R., \& Cornwell, B. T. (2011). Celebrity endorsement, brand credibility and brand equity. European Journal of Marketing, 45(6), 882-909. 
DOI: $10.14807 /$ ijmp.v12i4.1380

Srinivasan, N., \& Ratchford, B. T. (1991). An empirical test of a model of external search for automobiles. Journal of Consumer Research, 18(2), 233-242.

Turban, D. B., \& Greening, D. W. (1997). Corporate social performance and organizational attractiveness to prospective employees. Academy of Management Journal, 40(3), 658672.

Vidaver-Cohen, D. (2007). Reputation beyond the rankings: A conceptual framework for business school research. Corporate Reputation Review, 10(4), 278-304.

Vlachos, P. A., Tsamakos, A., Vrechopoulos, A. P., \& Avramidis, P. K. (2009). Corporate social responsibility: Attributions, loyalty, and the mediating role of trust. Journal of the Academy of Marketing Science, 37(2), 170-180.

Witkowska, J. (2016). Corporate social responsability: Selected theoretical and empirical aspects. Comparative Economic Research, 19(1), 27-43.

Zajac, E. J., \& Westphal, J. D. (1994). The costs and benefits of managerial incentives and monitoring in large US corporations: when is more not better? Strategic Management

Journal, 15(S1), 121-142. 